\title{
Trace metal concentrations in mussels: comparison between estuarine, coastal and offshore regions in the southeastern North Sea from 1983 to 1986
}

\author{
T. Borchardt, S. Burchert, H. Hablizel, L. Karbe, R. Zeitner \\ Institut für Hydrobiologie und Fischereiwissenschaft, Zeiseweg 9, D-2000 Hamburg 50, Federal Republic of Germany
}

\begin{abstract}
The blue mussel Mytilus edulis was used for monitoring trace metal contamination in the southeastern North Sea. From 1983 to 1986 more than 200 samples were collected from natural and cultured mussel beds, from groynes, anchor chains of nautical buoys and from biological monitoring stations. Soft bodies were analysed for mercury, cadmium, copper, silver, zinc and lead by atomic absorption spectrophotometry. Metal concentrations in mussels from the estuaries of Ems, Jade and Elbe were compared with those from the inner German Bight, from a region off southern Jylland, and the open sea. In some cases, $M$. edulis from offshore areas contained metal concentrations as high as specimens from the estuaries. Cadmium and lead concentrations increased from the inner German Bight towards the central North Sea. This is in contrast to the general distribution of trace metals in seawater. Using multiple regression analysis, a standard mussel was defined. Hence for each region normalized metal concentrations could be calculated. This approach provides a more realistic impression regarding regional contamination levels than using measured concentrations. Trace metal levels in mussels are influenced by season, size and body condition. For some regions temporal, mostly decreasing, trends in metal concentrations could be detected. It is suggested that the unexpected high cadmium and lead levels in mussels from the central North Sea are due to (1) changes in trace metal speciation - an increasing bioavailability counteracts declining concentrations in seawater towards the open sea $(2)$ the pattern of residual currents - a great part of the pollutants brought into the sea around the British Isles settles and accumulates in the central North Sea: (3) oxygen deficiencies - in certain regions this leads to pronounced changes in redox conditions in sediments, thus allowing remobilisation.
\end{abstract}

\section{INTRODUCTION}

Little information is available regarding trace metal contamination of benthic organisms in the open North Sea. Interest so far has been focussed on polluted coastal areas and so-called hot spots. In general it is assumed that on a transect from the coast to the central North Sea metal concentrations decrease. This paper examines this hypothesis and compares several regions of the southeastern North Sea by analysing trace metals in blue mussels Mytilus edulis. In this context some problems arise.

It is still doubtful whether there exists a simple relationship between trace metal concentrations in seawater and metal levels in marine organisms (Riisgård et al., in press). Although sometimes a power relation- ship may exist (Talbot 1985), in most cases it may be assumed that the time integrating accumulation of metals is a very complex process. It is governed by a large number of external and internal factors. Size (Cossa et al. 1979. Theede et al. 1979), sex (Orren et al. 1980), water temperature and salinity (Phillips 1976), food quality and quantity (Borchardt 1983), position in the food web, feeding habits, biochemical composition of the organism, genetic factors (Frazier \& George 1983, Lobel 1986), spawning cycle, benthic or pelagic way of life and the bioavailability of the trace metal species play a significant role for its accumulation. As a result variability of data from biomonitoring studies is quite pronounced. To a great extent this can be attributed to the seasonality of accumulation patterns (Boalch et al. 1981, Amiard et al. 1986). In general, peak concen- 
trations in mussels occur in late winter, and minimum values are found in autumn. The range of variation is about 2- to 3-fold.

To solve this problem it was proposed to investigate metal contamination under standardized conditions, i.e. samples would be taken at the same time of the year, at the same depths, from similar substratum, and organisms would be of comparable size and age.

This approach limits the ability to evaluate existing data sets compiled under non-standard conditions. Moreover the investigator is restricted to collecting samples only from a uniform environment. In reality these conditions hardly apply, especially when large areas must be examined.

In this study contamination of mussels from 6 different regions was investigated from 1983 to 1986 . These regions comprise the estuaries of Ems, Jade and Elbe Rivers, the inner German Bight, a region off southern Jylland and the open sea. The data set includes mussels from groynes, natural and cultured mussel beds, from anchor chains of nautical buoys and from biomonitoring stations. Measurements in the 3 estuaries cover different seasons, while samples from offshore regions were mainly collected in summer. Mussels from groynes were usually smaller and showed a lower body condition index than those from other sites. All this contributes to a strong inconsistency of sampling conditions. Nevertheless these difficulties cannot be avoided when comparing different regions.

As an alternative approach, a mathematical standardization of the samples was introduced, comparable to the established method of relating chlorinated hydrocarbons to fat content. In earlier studies, trace metal concentrations or body burdens respectively were related to shell weight (Fischer 1983), size and soft body dry weight (Cossa \& Rondeau 1985), size and fat content (Green et al. in press) and to size and body condition (Borchardt et al. in press). In the present paper temporal trends also were considered, as the period analysed covered an interval of $4 \mathrm{yr}$. After standardization the normalized metal concentrations of mussels from the different regions may be compared. This provides a more realistic view of regional contamination patterns than comparing the true, measured concentrations.

\section{MATERIAL AND METHODS}

There are 2 basic principles in conducting biomonitoring studies. Both the 'active' and 'passive' concept were realized in the present study. The active biomonitoring approach is based on exposing well characterized mussels under standardized conditions over a defined time span. Normally 2 size classes were used: $<3 \mathrm{~cm}$ and $>5 \mathrm{~cm}$ shell length. At start and end of the exposure period they were measured for shell length, shell weight, soft body fresh and dry weight, total volume, shell volume and trace metal concentrations. This approach has the advantage that many external conditions can be controlled, and that mussels can be exposed wherever desired.

Eighty large or 100 small individuals were placed in a net bag (mesh size $1 \mathrm{~cm}$ ). Their origin was either a mussel culture in Jade Bay or near Arendal (Norway). Norwegian mussels were classified as being 'low contaminated' and able to accumulate metals in the open sea. Eight bags were attached to an underwater
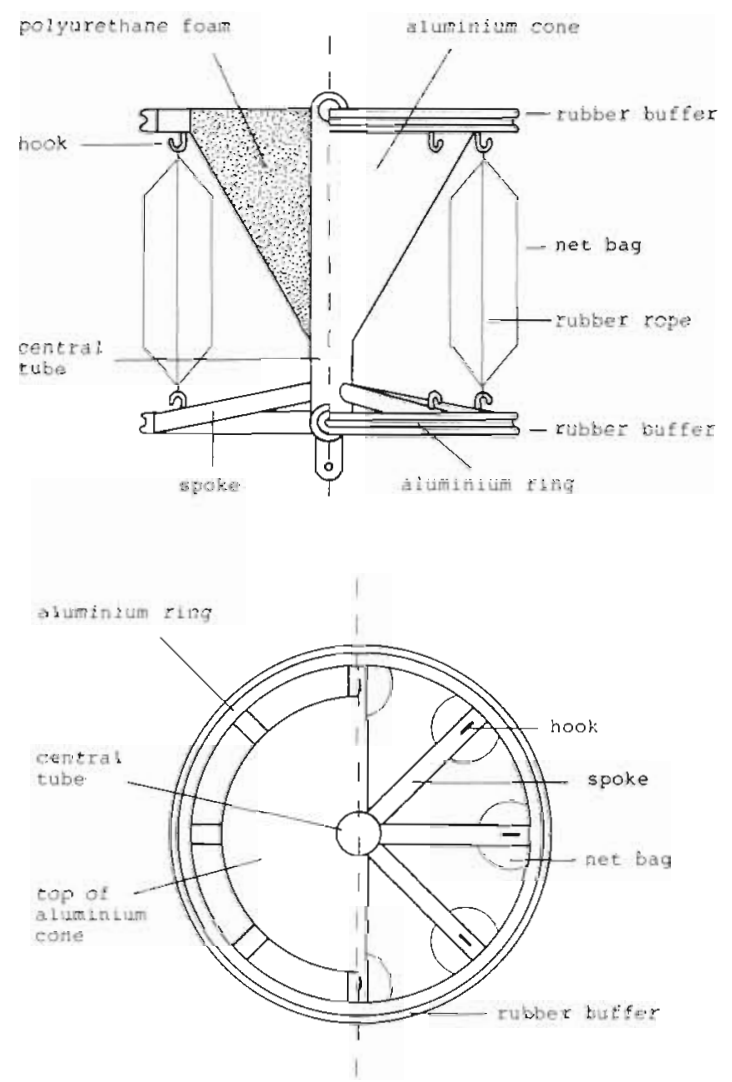

Fig. 1 Aluminium underwater buoy (diameter $1 \mathrm{~m}$, height $1 \mathrm{~m}$ ). Upper side view; lower top plan view

aluminium buoy (Fig. 1). Aluminium was chosen because it contains only negligible amounts of other trace metals, and because of its low specific weight. The buoy was filled with a polyurethan foam protecting it against leakage and giving a buoyancy of $68 \mathrm{kp}$. The cone shape reduces hydrodynamic resistance. Two rubber rings serve as buffers when the station is brought out or taken in from the research vessel.

Nearshore, this buoy was marked with orange plastic balls and secured by a usual fishery buoy (Fig. 2a). The mussels were suspended at a depth of about $4 \mathrm{~m}$, 

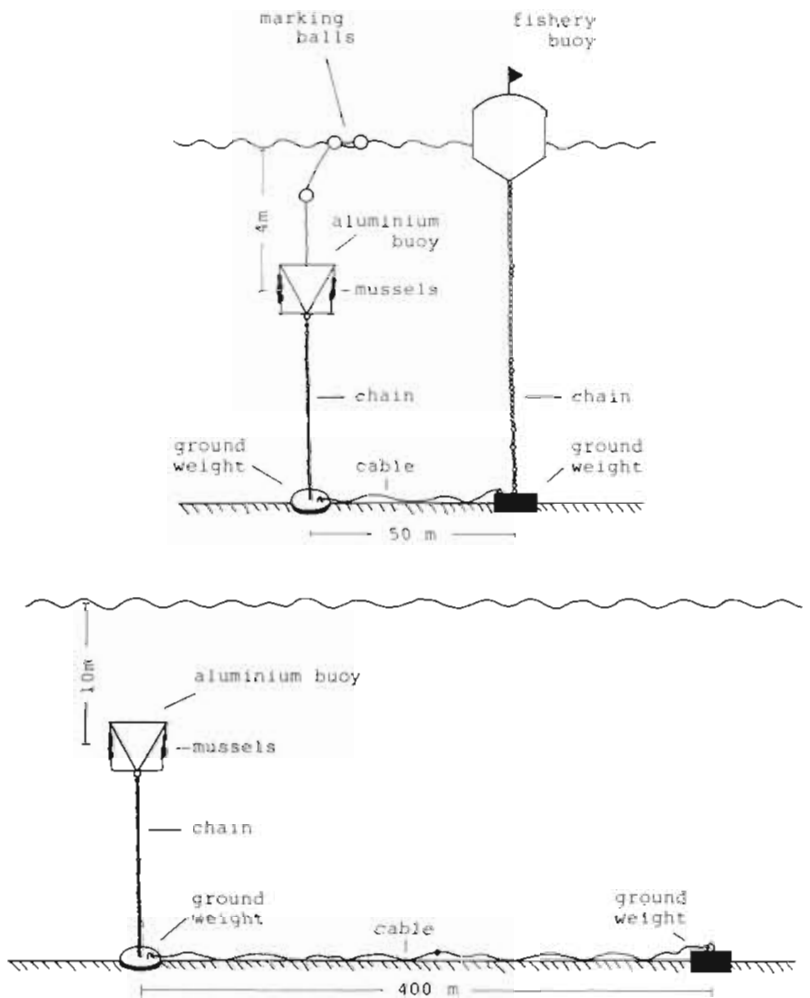

Fig. 2. Upper: Nearshore mussel watch station. Monitoring organisms are recovered by divers. The station is marked by orange plastic balls. Lower: Offshore mussel watch station. For recovery of the monitoring organisms the unmarked station is found by DECCA-navigation; the exact positions of ground weights are known

varying with the tides. The distance between the mussel watch station and the fishery buoy was $50 \mathrm{~m}$. Samples could easily be collected by research divers within a few minutes.

Offshore, the station was suspended at a depth of $10 \mathrm{~m}$ and was not marked. Only the position of the 2 ground weights was known exactly by DECCA-navigation. The weights were connected by a $400 \mathrm{~m}$ cable. For recovery of the biomonitoring organisms the complete station and its anchorage (Fig. 2b) had to be retrieved. This was accomplished by pulling a draganchor across the cable.

The passive biomonitoring approach simply collects mussels where they occur naturally. In the present study samples were taken from groynes, mussel beds and chains of nautical buoys. Samples from the anchor chains of buoys were taken by divers at $10 \mathrm{~m}$ depth to avoid the possible influence of metal-containing antifouling paints. If available, 30 to 50 individuals were combined in one sample.

Sampling sites (Fig. 3) were grouped into 6 regions. It was assumed that these water bodies were relatively homogenous as far as trace metals were concerned. They were termed Ems, Jade, Elbe regions, inner Ger- man Bight, southern Jylland, and open sea. Part of the non-estuarine, nearshore data was taken from Jensen (1985).

After collection, mussel shells were roughly cleaned. Depending on temperature, mussels were maintained in seawater for defaecation over a period of 1 or $2 \mathrm{~d}$.

Shells were then freed from epifauna, mainly Balanus sp. Individual shell length was measured, and total volume was determined by water displacement in a measuring cylinder. Mussels were induced to open their shells by putting them into a microwave oven (450 W) for about $2 \mathrm{~min}$. Then they were drained on filtering paper for $5 \mathrm{~min}$, positioned on the edges of their shells.

Soft bodies were separated from the shells using titanium-teflon-scapels. Shells were air dried for $1 \mathrm{wk}$, then shell weight was determined. Soft bodies were placed in Petri dishes. Wet weight was determined before, and dry weight after, freeze-drying at $-25^{\circ} \mathrm{C}$ and 0.05 Torr. Afterwards soft bodies were pulverized by an agat ball mill. An aliquot was pressure-digested (Tölg-apparatus, stepwise to $200^{\circ} \mathrm{C}, 65 \% \mathrm{HNO}_{3}$ ).

Metal concentrations were determined with a graphite furnace atomic absorption spectrophotometer (Perkin Elmer AAS 540 and AAS 2380, each coupled to a HGA 500 programmer) using a L'VOV-platform for higher sensitivity, precision and reproducibility.

From each sample 2 subsamples were analysed. At the start of each analytical series a standard addition was carried out using a laboratory-internal Mytilus edulis standard, intercalibrated with NBS standard reterence material 1577 (bovine liver). Subsequent samples were analysed directly, since matrices of blue mussels from different sites were very similar.

Mercury was determined by the cold vapour method (Perkin Elmer MAS 50).

To detect temporal trends, metal concentrations ( $\mathrm{y}$ ) were correlated with date, transformed into a decimal form $\left(\mathrm{x}=\right.$ date $\left._{\text {dec }}\right)$. Using the t-distribution trends were tested by

$$
t=\frac{b_{y x} \sqrt{\sum x^{2}-1 / n\left(\sum x\right)^{2}}}{\sqrt{\frac{\sum y^{2}-1 / n\left(\sum y\right)^{2}-b_{y x}\left(\sum x y-1 / n \sum x \sum y\right)}{n-2}}}
$$

To determine seasonal influences the date was transformed by a sine function simulating average water temperatures $\mathrm{T}$ The model predicts minimum water temperatures of $2^{\circ} \mathrm{C}$ at the end of February and maximum temperatures of $18^{\circ} \mathrm{C}$ at the end of August:

$$
\mathrm{T}=10+\left[8 \sin \left(\left[\text { date }_{\mathrm{dec}}-\text { INT date }_{\mathrm{dec}}\right] 360\right)+210\right](2)
$$

where INT date dec $=$ integer form of the demical date.

Regression analyses and statistical tests presupposed a normal distribution of the data used. This assumption was routinely checked by a range to standard deviation test (R/S-test, Sachs 1979). 
RESULTS

\section{Description of data sets}

Fig. 3 gives the positions of sampling sites. Between 1983 and 1986, 227 samples were taken at 50 different stations. With a few exceptions, all of them were analysed for mercury, cadmium, copper, silver, zinc and lead. From 1362 metal measurements, 7 were excluded from evaluation: 5 copper values might have been exceptionally enhanced due to a short term contamination of the respective estuaries, while 2 unusually high

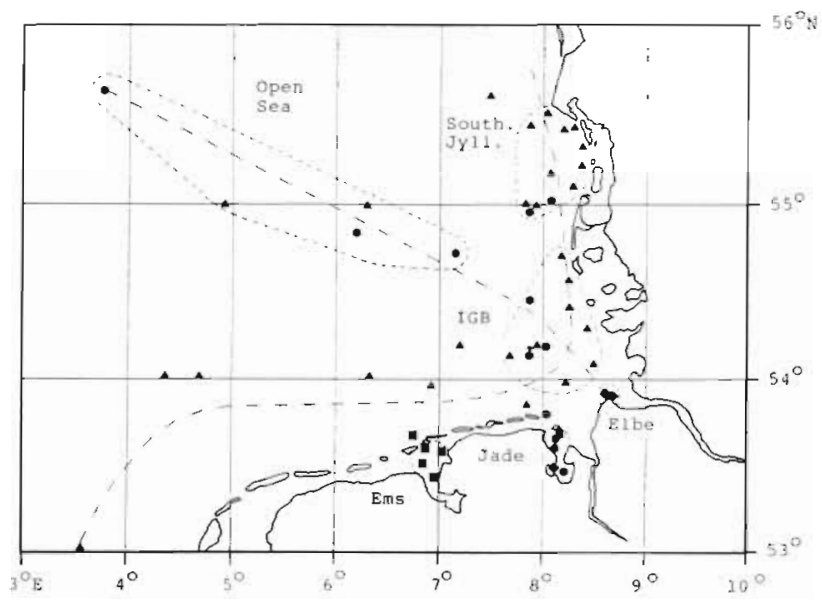

Fig. 3. Sampling sites for Mytilus edulis in the south eastern North Sea. (---) Transects for calculation of spatial trends; $(\ldots$.$) borders of regions; -$ biomonitoring station; $\Delta$ nautical

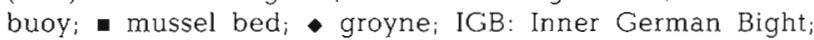
South Jyll.: southern Jylland

silver values might have been caused by contamination of the samples; moreover both silver samples were taken on the same day.

As pointed out previously (Borchardt et al. in press), metal concentrations correlate with a number of different parameters, especially the body condition index of the mussels. These findings were based on 2 sets of data; one comprised data from the Jade region (1982-1984); the other, from a transect along the German and Danish coast (1983, see Jensen 1985).

In this study, data from 6 different regions were evaluated over an extended period (1983-1986). Earlier findings were confirmed. The respective correlation matrices are given in Tables 1 a to f. From these matrices it is evident that changes in metal concentrations correlate - among other factors - with time course $t$, season (i.e. simulated water temperature $T$ ), soft body dry weight BDW, condition index $\mathrm{CI}$ as well as its inverse $1 / C I$, and shell length SL.

\section{Temporal trends}

To determine significant temporal trends, the data should cover at least a 3 yr period and should be evenly distributed in time. Of the 6 chosen regions, these presuppositions apply only to the data from the Ems, Jade and Elbe.

A significant decrease ( $p=0.05$ ) from 1983 to 1985 / 86 was determined for mercury concentrations in mussels from the Ems (Fig. $4 \mathrm{a}, 0.36 \rightarrow 0.16 \mathrm{mg} \mathrm{kg}^{-1}$ ) and Jade region $\left(0.38 \rightarrow 0.28 \mathrm{mg} \mathrm{kg}^{-1}\right)$, and for cadmium in the Jade $\left(2.0 \rightarrow 1.5 \mathrm{mg} \mathrm{kg}^{-1}\right)$ and Elbe region $\left(4.0 \rightarrow 2.1 \mathrm{mg} \mathrm{kg}^{-1}\right)$. Copper levels decreased in the Jade $\left(9.8 \rightarrow 6.8 \mathrm{mg} \mathrm{kg}^{-1}\right)$, as did zinc levels in the Jade $\left(143 \rightarrow 125 \mathrm{mg} \mathrm{kg}^{-1}\right)$ and the Elbe area $(167 \rightarrow 104 \mathrm{mg}$ $\left.\mathrm{kg}^{-1}\right)$. Only lead concentrations significantly increased in the Jade estuary $\left(1.7 \rightarrow 2.3 \mathrm{mg} \mathrm{kg}^{-1}\right)$. Hence 7 decreases in metal concentrations in Mytilus edulis occurred, with only one increase.

\section{Seasonal influences}

In the Ems, Jade and Elbe region in 9 of 18 cases seasonal oscillations of metal concentrations were found. They were inversely correlated with changes in the condition index (compare Fig. $4 \mathrm{a}$ and b). In general, a lower condition index leads to higher metal concentrations in the mussels. This means that in late winter and early spring maximum concentrations are reached, while lowest concentrations occur in early autumn. An exception is the Jade region. There, 3 of 5 sampling sites were biomonitoring stations, where the natural seasonal cycle does not take place: after nearly 1 yr of exposure the epifauna hinders a free exchange of seawater and oxygen between in- and outside of the net bags. So during times when the condition of the mussels improved elsewhere, in the Jade region it did not. This leads to a correlation coefficient near zero between metal concentrations and simulated water temperature.

Zinc and lead concentrations of Elbe mussels decreased in late winter and early spring. This can be attributed to lowered metal levels in the water at that time of the year, resulting from a dilution effect caused by ice and snow melting. Metals other than zinc and lead are less affected. Mercury and cadmium have long biological half lives and do not respond rapidly to lowered levels in the environment, while copper concentrations are relatively independent of external conditions.

The regions of the inner German Bight, southern Jylland and the open sea are represented only by data from the summer period. Hence correlation analyses regarding seasonal influences were not carried out. 
Table 1. Mytilus edulis. Matrices of correlation coefficients. (a) Ems region; (b) Jade region; (c) Elbe region; (d) open sea; (e) inner German Bight; (f) southern Jylland

\begin{tabular}{|c|c|c|c|c|c|c|c|}
\hline (a) & $\mathrm{CI}$ & $\mathrm{Hg}$ & $\mathrm{Cd}$ & $\mathrm{Cu}$ & $\mathrm{Ag}$ & $\mathrm{Zn}$ & $\mathrm{Pb}$ \\
\hline$t$ & $0.412^{\circ}$ & $-0.731 \cdots$ & 0.020 & 0.362 & -0.001 & -0.202 & -0.262 \\
\hline $\mathrm{T}$ & $0.850^{\circ}$ & $-0.740^{\cdots}$ & $-0.651^{\cdots}$ & -0.121 & -0.137 & $-0.490^{\circ}$ & 0.376 \\
\hline BDW & - & $-0.649^{\cdots}$ & -0.228 & 0.068 & 0.100 & 0.061 & 0.264 \\
\hline $\mathrm{CI}$ & - & $-0.795 \cdots$ & $-0.484^{\circ}$ & 0.080 & -0.197 & $-0.561^{\circ}$ & 0.111 \\
\hline $1 / \mathrm{CI}$ & - & $-0.788 \cdots$ & $0.457^{\circ}$ & -0.047 & 0.149 & $0.442^{\circ}$ & -0.109 \\
\hline SL & - & $-0.460^{\circ}$ & -0.009 & 0.301 & 0.242 & 0.493 & 0.108 \\
\hline $\mathrm{n}$ & 27 & 27 & 27 & 25 & 27 & 22 & 22 \\
\hline$r_{s}$ & 0.381 & 0.381 & 0.381 & 0.396 & 0.381 & 0.423 & 0.423 \\
\hline (b) & $\mathrm{CI}$ & $\mathrm{Hg}$ & $\mathrm{Cd}$ & $\mathrm{Cu}$ & $\mathrm{Ag}$ & $\mathrm{Zn}$ & $\mathrm{Pb}$ \\
\hline $\mathrm{t}$ & 0.018 & $-0.330^{\cdots}$ & $-0.201^{\prime}$ & $-0.538 \cdots$ & -0.106 & $-0.208^{\circ}$ & $0.243^{\circ}$ \\
\hline $\mathrm{T}$ & 0.012 & $-0.260^{\circ}$ & -0.156 & $-0.215^{\circ}$ & -0.179 & -0.137 & 0.128 \\
\hline BDW & - & $-0.406^{\cdots}$ & $-0.380^{\cdots}$ & $-0.228^{\circ}$ & $-0.265^{\circ}$ & $-0.519^{\circ}$ & $-0.222^{*}$ \\
\hline $\mathrm{CI}$ & - & $-0.711^{\cdots}$ & $-0.642 \cdots$ & $-0.384^{\cdots}$ & $-0.422^{\cdots}$ & $-0.524^{\cdots}$ & -0.146 \\
\hline $1 / \mathrm{CI}$ & - & $0.862^{\cdots}$ & $0.767^{\cdots}$ & $0.468^{\cdots}$ & $0.588^{\cdots}$ & $0.526^{\circ}$ & 0.062 \\
\hline $\mathrm{SL}$ & - & -0.080 & -0.110 & -0.085 & -0.110 & $-0.411^{\cdots}$ & $-0.188^{\circ}$ \\
\hline $\mathrm{n}$ & 115 & 115 & 115 & 115 & 108 & 108 & 109 \\
\hline$r_{s}$ & 0.183 & 0.183 & 0.183 & 0.183 & 0.189 & 0.189 & 0.188 \\
\hline (c) & $\mathrm{CI}$ & $\mathrm{Hg}$ & $\mathrm{Cd}$ & $\mathrm{Cu}$ & $\mathrm{Ag}$ & $\mathrm{Zn}$ & $\mathrm{Pb}$ \\
\hline $\mathrm{t}$ & 0.058 & 0.018 & $-0.488^{\circ}$ & -0.128 & -0.136 & $-0.557^{\circ}$ & -0.408 \\
\hline $\mathrm{T}$ & $0.433^{\circ}$ & $-0.648 \cdots$ & -0.325 & 0.193 & $-0.692 \%$ & $0.487^{\circ}$ & $0.514^{\circ}$ \\
\hline BDW & - & $-0.393^{\circ}$ & -0.074 & -0.284 & $-0.432^{\circ}$ & -0.020 & 0.039 \\
\hline $\mathrm{Cl}$ & - & $-0.555^{\circ}$ & $-0.776 \cdots$ & -0.121 & -0.324 & -0.256 & 0.135 \\
\hline $1 / \mathrm{CI}$ & - & $0.518^{\circ}$ & $0.806^{*}$ & 0.130 & 0.314 & 0.282 & 0.088 \\
\hline SL & - & 0.027 & $0.491^{\circ}$ & -0.151 & -0.212 & 0.165 & $-\hat{\mathrm{u}} .082$ \\
\hline$n$ & 28 & 28 & 28 & 25 & 28 & 21 & 21 \\
\hline$r_{s}$ & 0.374 & 0.374 & 0.374 & 0.396 & 0.374 & 0.433 & 0.433 \\
\hline (d) & CI & $\mathrm{Hg}$ & $\mathrm{Cd}$ & $\mathrm{Cu}$ & $\mathrm{Ag}$ & $\mathrm{Zn}$ & $\mathrm{Pb}$ \\
\hline $\mathrm{t}$ & $(0.232$ & 0.163 & $-0.537^{\circ}$ & -0.430 & $0.574^{\circ}$ & -0.470 & $\left.-0.647^{\circ}\right)$ \\
\hline$\Upsilon$ & - & - & - & - & - & - & - \\
\hline BDW & - & -0.091 & 0.094 & -0.059 & -0.047 & $0.557^{\circ}$ & 0.354 \\
\hline $\mathrm{CI}$ & - & $-0.545^{\circ}$ & -0.060 & 0.290 & -0.026 & $-0.622^{\circ}$ & -0.001 \\
\hline $1 / \mathrm{Cl}$ & - & $0.528^{\circ}$ & 0.038 & -0.113 & -0.140 & $0.724^{\circ}$ & 0.005 \\
\hline SL & - & 0.076 & 0.082 & -0.107 & 0.156 & $0.719^{\circ}$ & 0.256 \\
\hline $\mathrm{n}$ & 16 & 16 & 16 & 16 & 15 & 15 & 15 \\
\hline$r_{5}$ & 0.497 & 0.497 & 0.497 & 0.497 & 0.514 & 0.514 & 0.514 \\
\hline (e) & $\mathrm{CI}$ & $\mathrm{Hg}$ & $\mathrm{Cd}$ & $\mathrm{Cu}$ & $\mathrm{Ag}$ & $\mathrm{Zn}$ & $\mathrm{Pb}$ \\
\hline$t$ & $\left(-0.895^{\circ}\right.$ & $-0.641^{\prime}$ & $0.877^{\cdots}$ & $0.821^{\circ}$ & -0.842 & 0.185 & $0.123)$ \\
\hline$T$ & - & - & - & - & - & - & - \\
\hline BDW & - & -0.448 & $0.763^{\circ}$ & $0.836^{\circ}$ & 0.994 & 0.559 & 0.318 \\
\hline $\mathrm{Cl}$ & - & 0.446 & $-0.826^{\circ}$ & $-0.842^{\circ}$ & -0.882 & -0.402 & -0.364 \\
\hline $1 / \mathrm{CI}$ & - & -0.553 & $0.884^{\cdots}$ & $0.811^{\circ}$ & 0.894 & 0.503 & 0.202 \\
\hline $\mathrm{SL}$ & - & -0.313 & 0.491 & $0.711^{\circ}$ & 0.702 & 0.369 & 0.581 \\
\hline $\mathrm{n}$ & 11 & 11 & 11 & 11 & 3 & 11 & 11 \\
\hline$I_{s}$ & 0.602 & 0.602 & 0.602 & 0.602 & 0.997 & 0.602 & 0.602 \\
\hline
\end{tabular}


Table 1 (continued)

\begin{tabular}{|c|c|c|c|c|c|c|c|}
\hline (f) & $\mathrm{Cl}$ & $\mathrm{Hg}$ & $\mathrm{Cd}$ & $\mathrm{Cu}$ & Ag & $\mathrm{Zn}$ & $\mathrm{Pb}$ \\
\hline $\mathrm{t}$ & $(-0.784 \cdots$ & $-0.532^{\circ}$ & 0.490 & $0.535^{\circ}$ & 0.628 & -0.360 & $\left.0.687^{\circ}\right)$ \\
\hline $\mathrm{T}$ & - & - & - & - & - & - & - \\
\hline BDW & - & -0.351 & $0.678^{\circ}$ & -0.179 & -0.816 & -0.077 & $0.709^{\circ}$ \\
\hline $\mathrm{CI}$ & - & 0.221 & $-0.717^{\circ}$ & -0.270 & 0.009 & -0.055 & $-0.791 \cdots$ \\
\hline $1 / \mathrm{CI}$ & - & 0.023 & $0.839^{\cdots}$ & 0.207 & -0.062 & 0.332 & $0.729^{\circ}$ \\
\hline $\mathrm{SL}$ & - & -0.164 & $0.757^{\circ}$ & -0.071 & -0.801 & -0.009 & $0.702^{\circ}$ \\
\hline n & 15 & 14 & 15 & 15 & 5 & 15 & 15 \\
\hline$r_{s}$ & 0.514 & 0.532 & 0.514 & 0.514 & 0.878 & 0.514 & 0.514 \\
\hline
\end{tabular}
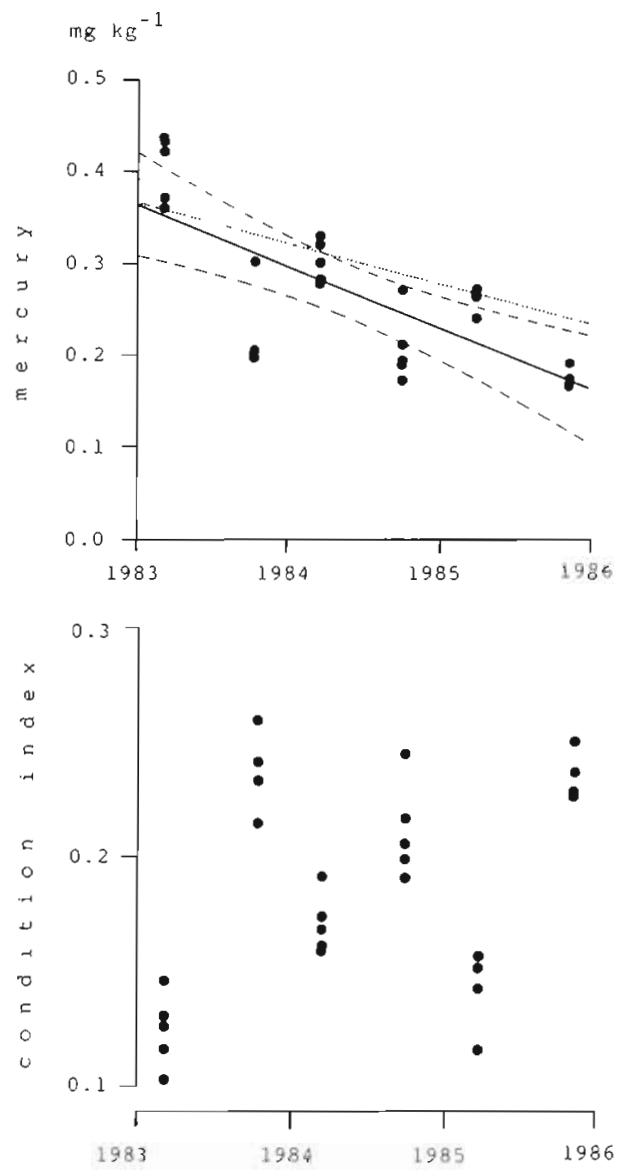

Fig. 4. Mytilus edulis. Upper Mercury concentrations in Ems region from 1983 to $1985 / 86$. (- - ) Limits of confidence for regression line at $p=0.05 ;(\cdots)$ regression line after normalization to standard length and standard condition. Lower. Seasonal oscillations of condition index with time (Ems region)

\section{Dependency on soft body dry weight}

In all estuarine and nearshore regions, when there was a significant correlation, metal concentrations decreased with enhanced soft body dry weight. This occurred in 9 of 18 cases. In the offshore regions only on 5 occasions a significant correlation was found, but - in contrast - metal concentrations increased with soft body dry weight.

\section{Dependency on condition index}

Concentrations of mercury, cadmium and zinc were-in 12 of 18 cases $(p=0.05)$ - negatively correlated with the condition index $\mathrm{CI}=\mathrm{BDW} / \mathrm{SW}$ (Fig. 5a), and positively with its inverse SW/BDW (Fig. 5b). The use of $1 /$ CI gives a better fit, especially when data comprise mussels in particularly low condition, e.g. mussels from groynes. For copper, silver and lead this relation was less pronounced. In nearly all cases the condition index showed a covariation with simulated water temperature $T$. These typical seasonal oscillations were not found in the Jade mussels, as mentioned above.

\section{Dependency on shell length}

Only in a few cases (zinc and lead) were metal concentrations dependent on mussel size (Fig. 6).

\section{Multiple relationships}

Although metal concentrations in mussels depend on a large number of parameters, the correlation matrices show that variability frequently can be explained by one single factor Nevertheless it is a more realistic approach to carry out a multiple correlation analysis and try to explain variability by the interaction of several factors. 

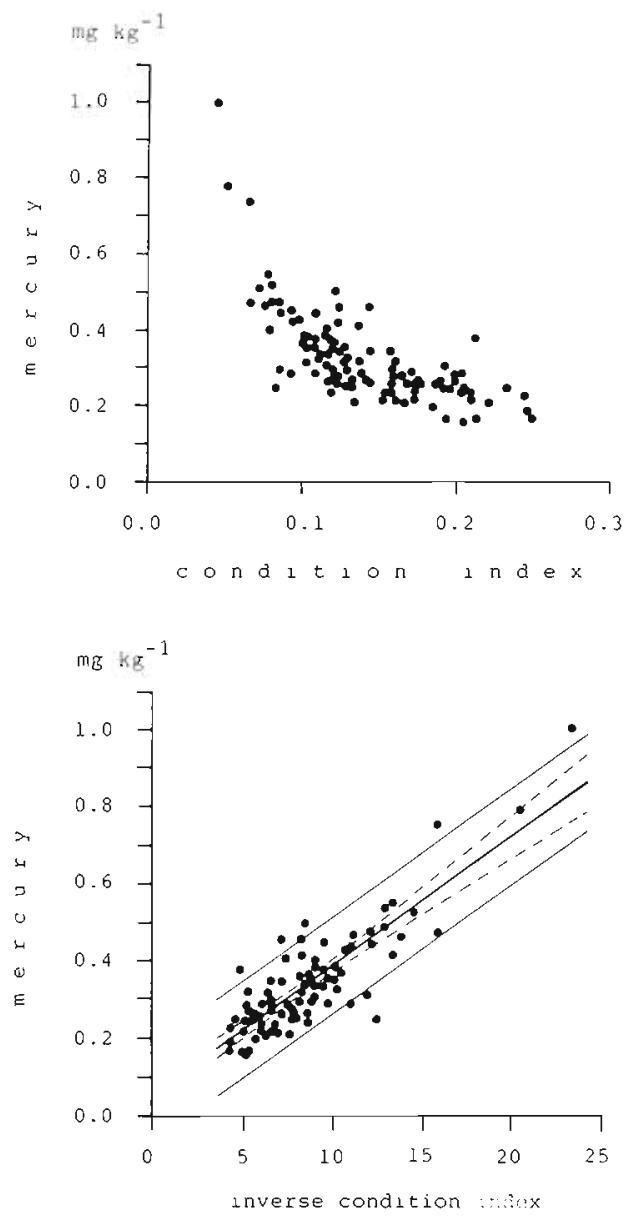

Fig. 5. Mytllus edulis. Upper: Mercury concentrations in Jade mussels plotted against condition index BDW/SW. Lower: Correlation between mercury concentrations in Jade mussels and inverse condition index SW/BDW. (-- ) Limits of confidence for regression line; $(-)$ limits of confidence for single mercury values, $p=0.05$

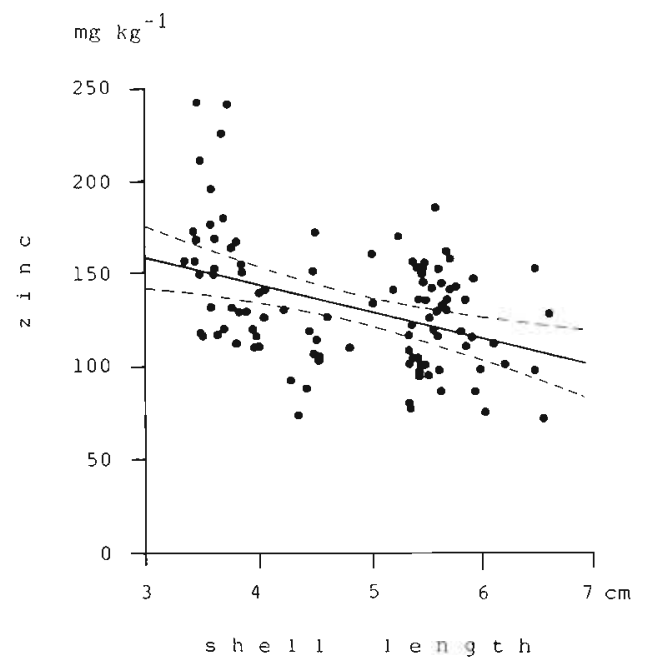

Fig. 6. Mytilus edulis. Correlation between zinc concentrations in Jade mussels and shell length. (-- ) Limits of confidence for the regression line at $p=0.05$
In Table 2, multiple correlation coefficients are given for an equation of the type

$$
\text { Metal conc }=a+b t+c S L+d 1 / C I
$$

The data show that in a uniform, well-mixed water body, like the Jade estuary, variability in all 6 metal concentrations can be explained by time (t), size (SL) and body condition (CI). In Ems, Elbe and southern Jylland this is only valid for 3 metals. For the inner German Bight and the open sea it applies only to 2 metals. Conspicuously, in contrast to the 1 -factor correlation analysis, lead becomes one of the elements which is strongly influenced by a combination of internal and external factors.

In summary, variability in metal concentrations in mussels could, in 27 of 36 cases $(75 \%)$, be attributed to the influence of 1 factor, or to the combined effects of the 3 parameters time, size and body condition (Table 3 ). It is stressed that this statement is based on variability and not on metal level.

For the other $25 \%$, variability must have been due to factors not considered, to variations in trace metal concentrations in the environment, or to inhomogenities in the respective seawater bodies.

\section{Spatial trends}

Fig. 3 shows 2 transects. One extends trom the Elbe estuary to the open sea, the other runs parallel to the coastline from the Netherlands to Denmark. The different stations lie within limits of about 20 nautical miles along these transects. In Figs. 7 and 8 , metal concentrations are plotted against distance from the starting points of these transects.

A significant decrease $(p=0.05)$ of metal concentrations in mussels on a transect from the inner German Bight to the open sea was found only for mercury (Fig. 7a: $0.32 \rightarrow 0.12 \mathrm{mg} \mathrm{kg}^{-1}$ ). For copper, silver and zinc no significant trends were detected. The most striking result was that cadmium and lead concentrations rose with increasing distance from the coast (Fig. 7b, c: cadmium, $0.8 \rightarrow 3.2 \mathrm{mg} \mathrm{kg}^{-1}$; lead, 1.3 $\rightarrow 2.6 \mathrm{mg} \mathrm{kg}^{-1}$ ).

Along the transect parallel to the coast, significant peak concentrations of mercury, cadmium, zinc and lead were detected near the Jade and/or Elbe estuary (Fig. 8). When comparing average coastal concentrations with enhanced concentrations in front of these estuaries, the following results were obtained: mercury, average concentrations of about $0.2 \mathrm{mg} \mathrm{kg}^{-1} \mathrm{vs}$ $0.4 \mathrm{mg} \mathrm{kg}^{-1}$ peak concentrations; cadmium, 0.8 to 2.5 ; zinc, $<100$ to 165 ; lead, 1.0 to $2.5 \mathrm{mg} \mathrm{kg}^{-1}$. 
Table 2. Mytilus edulis. Matrix of multiple correlation coefficients

\begin{tabular}{|c|c|c|c|c|c|c|c|}
\hline Region & & $\mathrm{Hg}$ & $\mathrm{Cd}$ & $\mathrm{Cu}$ & $\mathrm{Ag}$ & $\mathrm{Zn}$ & $\mathrm{Pb}$ \\
\hline \multirow[t]{3}{*}{ Ems } & $\mathrm{r}$ & $0.897^{\cdots}$ & $0.537^{\circ}$ & 0.443 & 0.365 & $0.616^{\circ}$ & 0.297 \\
\hline & $r_{s}$ & 0.532 & 0.532 & 0.552 & 0.532 & 0.587 & 0.587 \\
\hline & $\mathrm{n}$ & 27 & 27 & 25 & 27 & 22 & 22 \\
\hline \multirow[t]{3}{*}{ Jade } & $\mathrm{r}$ & $0.895^{\cdots}$ & $0.775^{\cdots}$ & $0.675^{\cdots}$ & $0.589^{\cdots}$ & $0.643^{\cdots}$ & $0.316^{\circ}$ \\
\hline & $r_{\mathrm{s}}$ & 0.260 & 0.260 & 0.260 & 0.263 & 0.268 & 0.267 \\
\hline & $\mathrm{n}$ & 115 & 115 & 115 & 112 & 108 & 109 \\
\hline \multirow[t]{3}{*}{ Elbe } & $\mathrm{r}$ & $0.559^{\circ}$ & $0.918^{\cdots}$ & 0.278 & 0.491 & $0.690^{\circ}$ & 0.424 \\
\hline & $\mathrm{r}_{\mathrm{s}}$ & 0.552 & 0.522 & 0.552 & 0.552 & 0.600 & 0.600 \\
\hline & $\mathrm{n}$ & 28 & 28 & 25 & 28 & 21 & 21 \\
\hline \multirow[t]{3}{*}{ Open sea } & $\mathrm{r}$ & 0.666 & 0.581 & 0.598 & 0.722 & $0.879^{\circ}$ & $0.749^{\circ}$ \\
\hline & $r_{s}$ & 0.682 & 0.682 & 0.682 & 0.703 & 0.703 & 0.703 \\
\hline & $\mathrm{n}$ & 16 & 16 & 16 & 15 & 15 & 15 \\
\hline \multirow[t]{3}{*}{ Inner Germ. Bight } & I & 0.675 & $0.974^{\cdots} \cdots$ & $0.846^{\circ}$ & - & 0.769 & 0.733 \\
\hline & $r_{5}$ & 0.806 & 0.806 & 0.806 & - & 0.806 & 0.806 \\
\hline & $\mathrm{n}$ & 11 & 11 & 11 & 3 & 11 & 11 \\
\hline \multirow[t]{3}{*}{ South. Jylland } & $r$ & 0.691 & $0.893^{\cdots}$ & 0.701 & 0.829 & $0.808^{\cdots}$ & $0.827^{\cdots}$ \\
\hline & $x_{s}$ & 0.725 & 0.703 & 0.703 & 0.999 & 0.703 & 0.703 \\
\hline & $\mathrm{n}$ & 14 & 15 & 15 & 5 & 15 & 15 \\
\hline
\end{tabular}

Table 3. Mytilus edulis. Summary of significant correlations

\begin{tabular}{lllllll|}
\hline Region & $\mathrm{Hg}$ & $\mathrm{Cd}$ & $\mathrm{Cu}$ & $\mathrm{Ag}$ & $\mathrm{Zn}$ & $\mathrm{Pb}$ \\
\hline Ems & + & + & - & - & + & - \\
Jade & + & + & + & + & + & + \\
Elbe & + & + & - & + & + & + \\
Open sea & + & + & - & + & + & + \\
Inn. Germ. Bight & + & + & + & - & - & - \\
South. Jylland & + & + & + & - & + & + \\
Plus (+): variability in the respective trace metal concen- \\
tration can be explained by one, or by interaction of sever- \\
al variables at $\mathrm{p}=0.05$
\end{tabular}

\section{Regional differences}

Concentrations of cadmium, silver and lead in Mytilus edulis from the open sea are surprisingly high. Maximum cadmium values in mussels from the station most distant from the coast were as high as peak values from the Elbe estuary (5.4 $\mathrm{mg} \mathrm{kg}^{-1}$ ). Also, for silver, highest concentrations were not measured nearshore, but in the region around Helgoland (ca $50 \mathrm{~km}$ offshore in the German Bight), and in the open sea $(0.3 \mathrm{mg}$ $\mathrm{kg}^{-1}$ ). Maximum lead values are reported from the Jade region, but on average mussels from the open sea seem to be similarly contaminated.

When all 6 regions were compared, Elbe estuary mussels showed the most elevated metal levels. There, highest average concentrations were found for mercury $\left(0.78 \mathrm{mg} \mathrm{kg}^{-1}\right)$, cadmium $\left(3.3 \mathrm{mg} \mathrm{kg}{ }^{-1}\right)$, copper ( $8.4 \mathrm{mg}$ $\mathrm{kg}^{-1}$ ) and zinc (139 $\mathrm{mg} \mathrm{kg}^{-1}$ ).

The lowest contamination occurred in the area off southern Jylland. Average concentrations of mercury were $0.19 \mathrm{mg} \mathrm{kg}^{-1}$; cadmium, $0.8 \mathrm{mg} \mathrm{kg}^{-1}$; zinc, $99 \mathrm{mg}$ $\mathrm{kg}^{-1}$; lead, $0.9 \mathrm{mg} \mathrm{kg}^{-1}$; they all lie in the lower range.

In the Ems region generally low values were measured for silver (0.12 $\mathrm{mg} \mathrm{kg}^{-1}$ ) and zinc (95 $\left.\mathrm{mg} \mathrm{kg}^{-1}\right)$. Values for the other metals lie in the range of mean concentrations.

In the Jade estuary, clearly elevated lead values were found (average: $2.0 \mathrm{mg} \mathrm{kg}{ }^{-1}$ ). This might be due to the lead industry of that region. Mercury and zinc contamination was relatively high $(0.32$ and $132 \mathrm{mg}$ $\mathrm{kg}^{-1}$, respectively). In contrast, comparatively low average silver concentrations $\left(0.33 \mathrm{mg} \mathrm{kg}^{-1}\right)$ were determined,

Around Helgoland and in a wider sense in the inner German Bight the waters seem to be strongly contaminated due to a number of different influences, especially the Elbe river. High mercury $\left(0.31 \mathrm{mg} \mathrm{kg}{ }^{-1}\right)$, silver $\left(0.33 \mathrm{mg} \mathrm{kg}^{-1}\right)$ and zinc (130 $\mathrm{mg} \mathrm{kg}^{-1}$ ) average contaminations were measured.

Average metal concentrations (arithmetic mean of the respective region) are illustrated in Fig. $9 \mathrm{a}$ to $\mathrm{f}$. Values from different regions are not strictly comparable, since large mussels are compared with small ones, subtidal with intertidal ones, data from summer with those of winter, and concentrations from 1983 with 

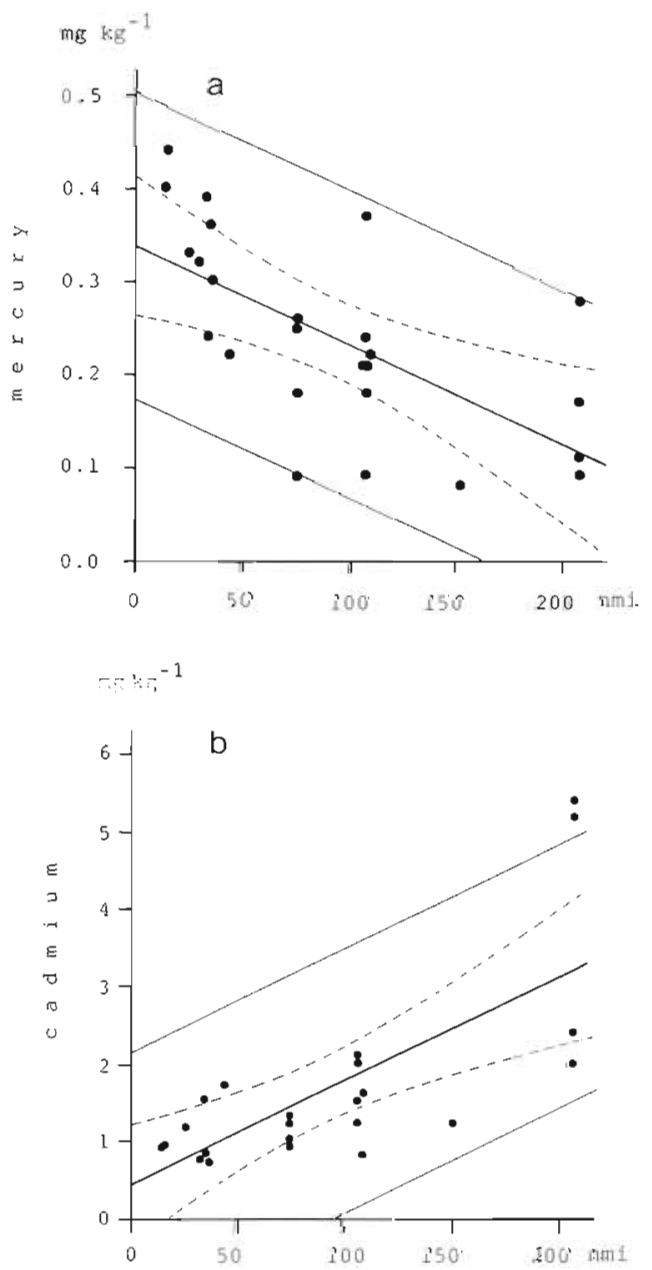

those from 1986. Even sampling sites may vary in the course of the years, according to the availability of research vessels, the magnitude of the annual budget and changes in research programmes. Under such varying conditions only a very rough estimate can be obtained of the contamination levels in different regions.

To overcome this problem, multiple regression analysis was used and normalized metal concentrations of standard mussels were calculated. These mussels were defined as having a shell length of $4 \mathrm{~cm}$, a condition index of 0.15 , and a collection date of 1 Jun 1985. Parameters were chosen in such a way that their magnitude lay in the overlapping range of all 6 data sets. This was necessary, for example, since parameters of the largest mussels in best body condition from the Elbe estuary corresponded to those of the smallest mussels in worst body condition from the Ems region. However, when linearly extrapolating into a range of magnitude that is not represented by values of the respective data set, the calculated metal concentration may be misleading.

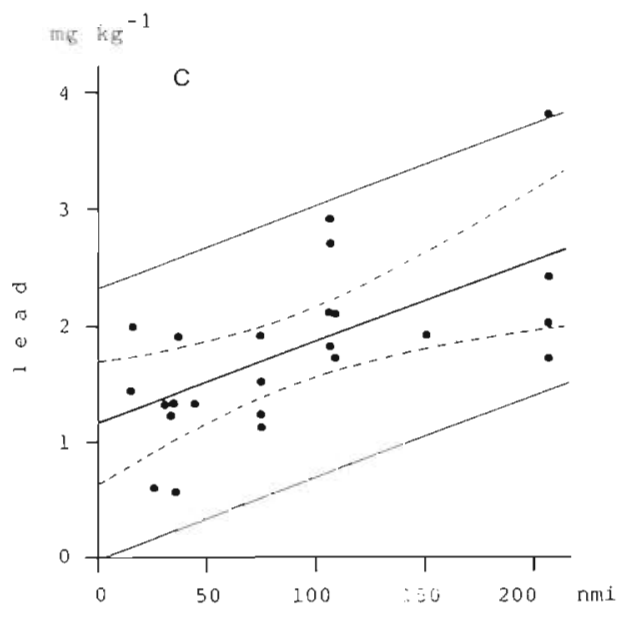

Fig. 7. Mytilus edulis. Trace metal concentrations on a transect from the Elbe estuary (0 $\mathrm{nmi}$ ) via the inner German Bight to the open sea. (-- ) Limits of confidence for regression line; $(-)$ limits of confidence for single values, $p=0.05$ ). (a) Mercury; (b) cadmium; (c) lead

In general, as a result of normalization the metal contamination of estuarine mussels declines, and that of the open sea mussels increases. Differences between regions are partly levelled, but not eliminated. Temporal trends become less evident (Fig. 4a) or more evident depending on the covariation of other correlated parameters. Thus real temporal changes in trace metal contamination can be distinguished from fictitious ones.

\section{DISCUSSION}

Our study has shown that trace metal concentrations in mussels Mytilus edulis are influenced by a number of different parameters which modify the characteristic level of regional contamination. As a consequence the variability of data from long-term biological monitoring programmes is quite pronounced. However, it can largely be explained by only 3 factors: sampling date, size of the mussels, and body condition.

The sampling date represents season (water temperature, phytoplankton and trace metal availability) on 

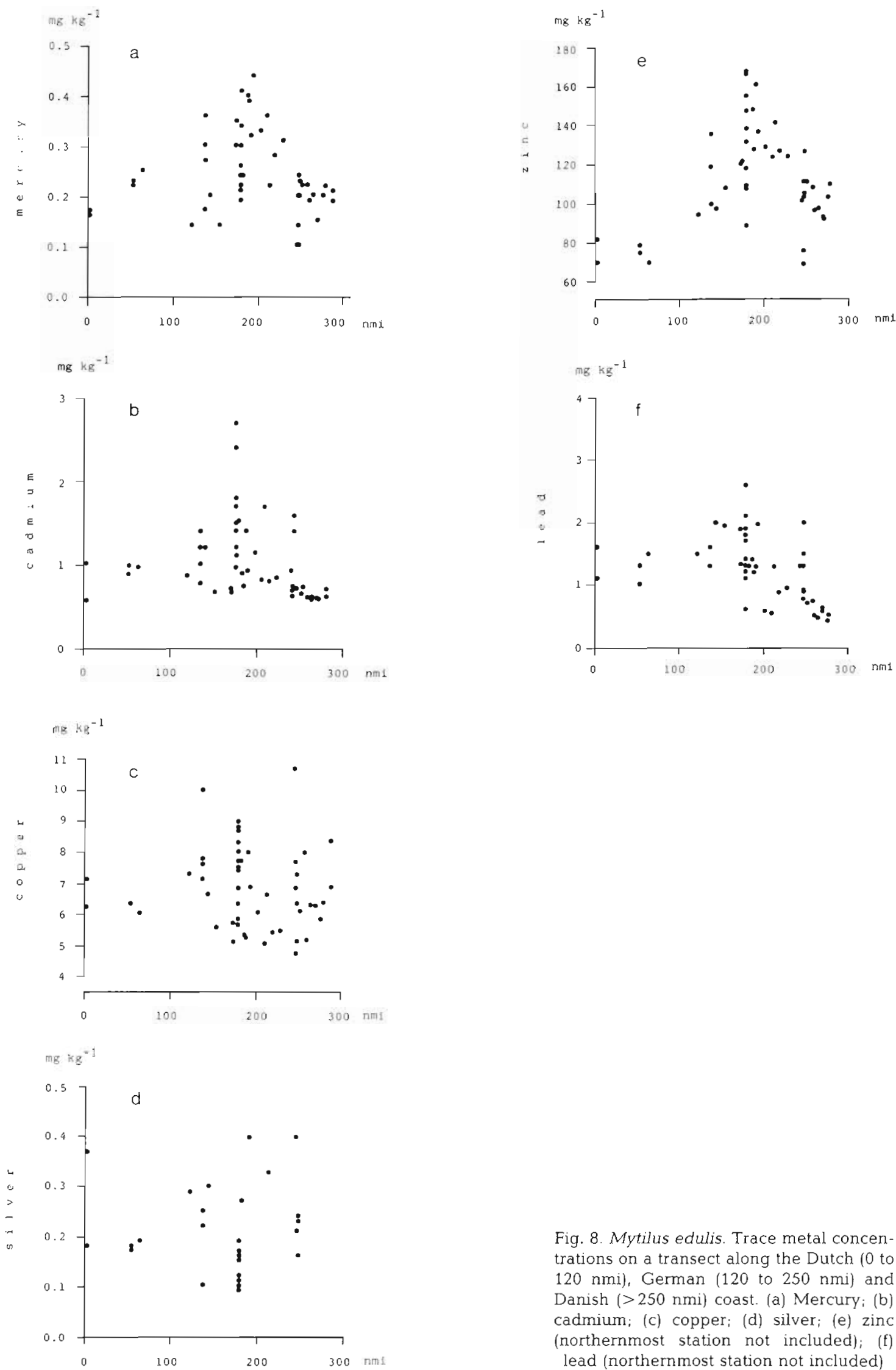

Fig. 8. Mytilus edulis. Trace metal concentrations on a transect along the Dutch 10 to $120 \mathrm{nmi}$ ), German (120 to $250 \mathrm{nmi}$ ) and Danish (>250 nmi) coast. (a) Mercury; (b) cadmium; (c) copper; (d) silver; (e) zinc (northernmost station not included); (f) lead (northernmost station not included) 

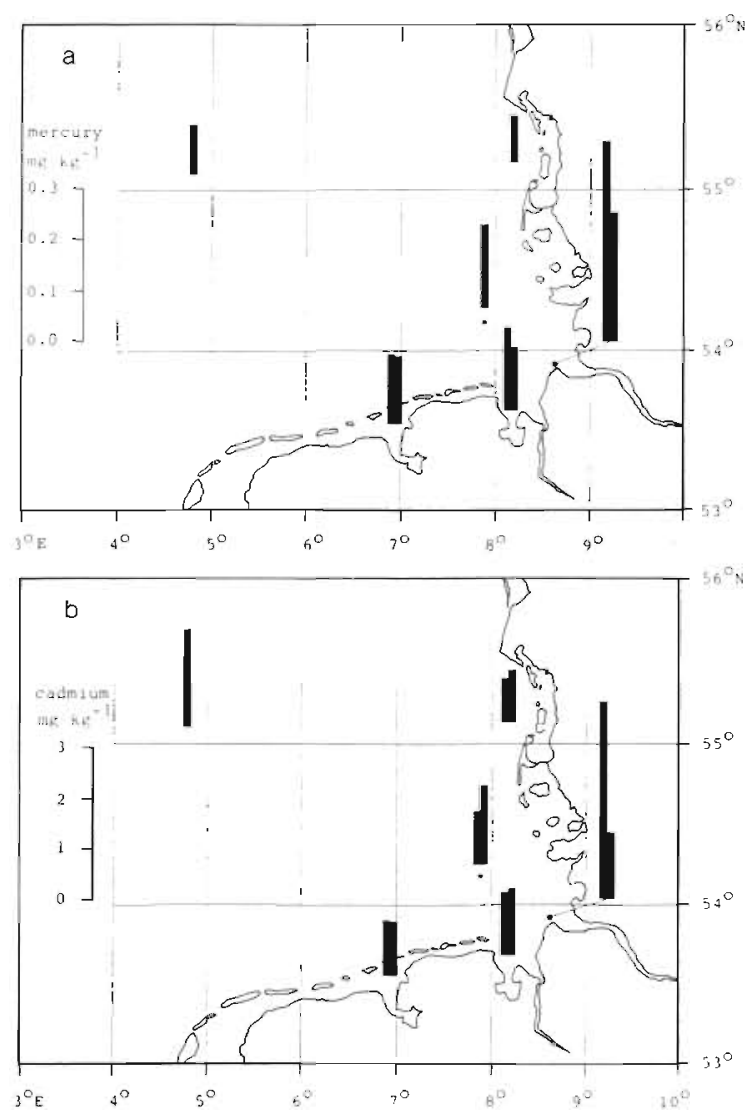

Fig. 9. Mytilus edulis. Average and normalized trace metal concentrations in the southeastern North Sea. The left (or only) column corresponds to average, the right to normalized concentration. (a) Mercury; (b) cadmium; (c) copper; (d) silver; (e) zinc; (f) lead
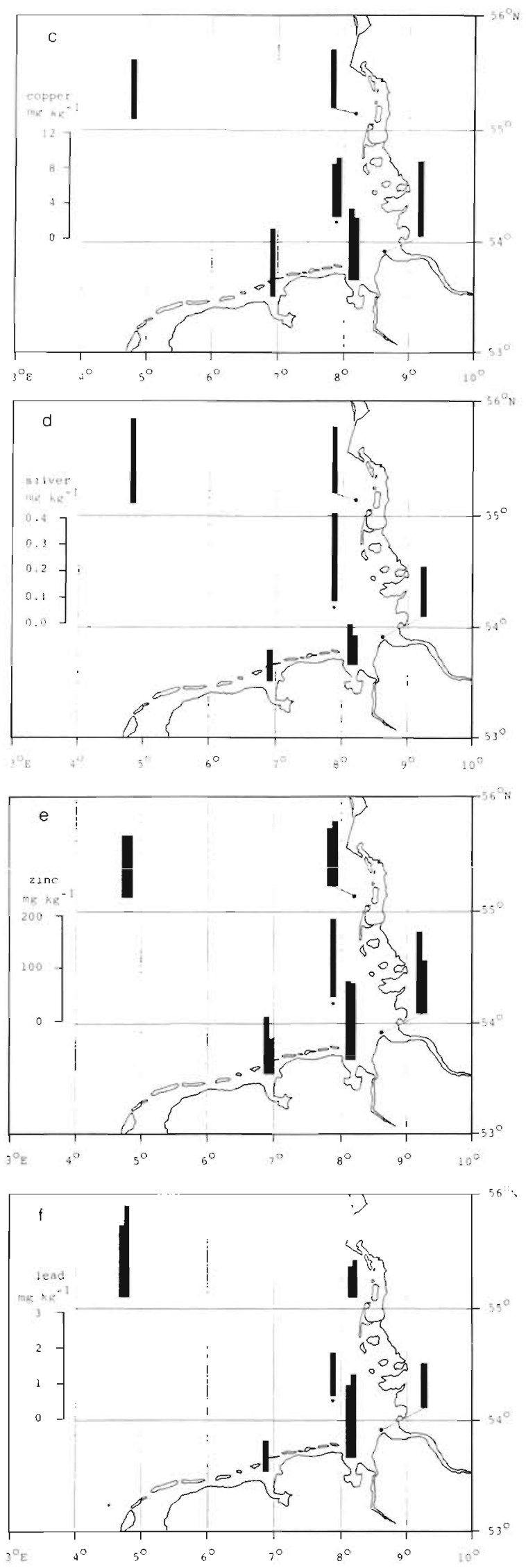
the one hand, and on the other hand time course (temporal trends in metal contamination). The size results from the combined effects of growth and age. Changing body condition index reflects nutritional condition as well as the stage in the reproductive cycle.

Hence statements about contamination of certain regions in the sea should be based on more than one sampling date or period. As demonstrated by Boalch et al. (1982), Amiard et al. (1986) and the present study, seasonal variations follow a sinusoidal curve. In general, this leads to enhanced trace metal concentrations in winter and to lowered concentrations in summer. A simple explanation favours the assumption that during the growth period in late spring and summer trace metals are diluted by increasing biomass. This pattern might by modified in estuaries of large rivers. There, in late winter the dilution of pollutants in the water is highest due to maximum water flow rates, caused by increased precipitation, as well as melting ice and snow. This is reflected in relatively low concentrations of trace metals with short biological half lives in the mussels in late winter or early spring.

The effect of body condition on metal levels in mussels is most prominent. In the 6 regions, without exception, variations in mercury and cadmium concentrations were dependent on the condition index. When all trace metals under investigation are considered this dependency still holds for $2 / 3$ of all cases. For example, Fig. 5b demonstrates that metal concentrations varying by a factor of 5 correlate very well with the inverse condition index alone.

Many authors emphasize the interrelation between shell size and metal levels (Theede et al. 1979, Latouche \& Mix 1982), although their conclusions may differ. Fischer (1983) found that large mussels contain higher cadmium concentrations, while Cossa et al. (1979) determined relatively high values in small mussels. The present study confirms that in some cases size plays a significant role. However, date of sampling and body condition are much more important for assessing accumulations of metals.

As pointed out a number of internal and external factors control trace metal concentrations in mussels. To obtain comparable results, exposure conditions should be standardized. This is not always possible, especially not when subsamples of local populations are collected. Consequently, age, size, sampling depth, food supply, exposure to currents, waves, air and suspended solids may vary. Moreover, when long-term studies are conducted, seasonal and temporal effects must be taken into account. Hence mathematical standardisation seems to be advantageous. The magnitude of standardized parameters should be defined within the overlapping range of all data sets to avoid misinterpretations.
A meaningful normalization of trace metal concentrations pre-supposes relatively homogenous water bodies in the respective regions. Otherwise differences in contamination levels of different regions could not be detected, or the influence of certain external factors would mask the effects of differing seawater metal concentrations. Hence the method employed for defining regions with characteristic properties is of importance.

In the present study demarcation lines of regions were chosen according to plausibility. The correlation matrix of Table 3 shows that this approach was quite successful, since $75 \%$ of the variability in the data could be explained by only 3 factors. In other cases a statistical approach might be more promising, so that when the data are sufficient - isoclines can be drawn separating various regions from another. Also the boxand-whisker-plot method can be applied to this problem (McGill et al. 1978).

After normalization, quite often the differences between estuarine and offshore mussels are levelled, that is, low concentrations in the open sea become enhanced and high concentrations in the estuaries are lowered. This does not mean that differences become insignificant. Cadmium concentrations in mussels from the Elbe estuary serve as an outstanding example. The extremely low normalized cadmium concentration compared to the average measured concentration can be explained by the combination of at least 2 facts: (1) Elbe mussels were collected from a groyne. Depending on tides they were periodically air exposed, the remainder of the time they were subject to wave action and changing salinities. High loads of pollutants and suspended matter act as another stress on the animals. All this leads to an extremely low average condition index of 0.086 . However, a low condition index is always and everywhere coupled with a high cadmium content. The standard mussel was defined as having a condition index of 0.15 which is still in the lower range of all regions, but represents the highest value found in the Elbe mussels. This means that the normalized cadmium concentration is decreased drastically when a 'normal' body condition is assumed. (2) From the beginning of 1983 to the end of 1985 cadmium concentrations in mussels from the Elbe estuary decreased pronouncedly from about 4.5 to $2.5 \mathrm{mg} \mathrm{kg}^{-1}$, while in the open sea the levels were more constant. The standard mussel was defined as having been collected on 1 Jun 1985. This means that the normalized cadmium concentration of the Elbe mussels was lower than the average concentration, because the date mentioned was set more towards the end of the 3 yr period.

Overall, there was one uniform tendency: when a transect along the coastline from the Netherlands to Denmark was considered, all 6 metals showed peak 
concentrations in the inner German Bight. This can be attributed to the influence of the Elbe river. Only the northernmost station far off the Danish coast does not fit into this scheme. Here zinc and lead concentrations were unusually high. This corresponds to the findings of other investigators who found enhanced trace metal concentrations in this area in Limanda limanda (Claussen $1987 \mathrm{a}, \mathrm{b}$ ). Moreover this region is strongly affected by fish diseases (Dethleffsen 1984) and lowered oxygen saturation (Weichart 1984). So far the results of this study are in accordance with common views about the pattern of contamination in the southeastern North Sea.

Most striking is the fact that especially cadmium and lead, and less pronounced silver, concentrations in mussels were surprisingly high in the central North Sea. Cadmium peak values from the open sea were comparable to peak values in the Elbe region. For silver, concentrations were even lower in the Elbe estuary than in the open sea. Although this seems to be a paradox, similar results for mercury, cadmium and lead were obtained in Limanda limanda by Claussen
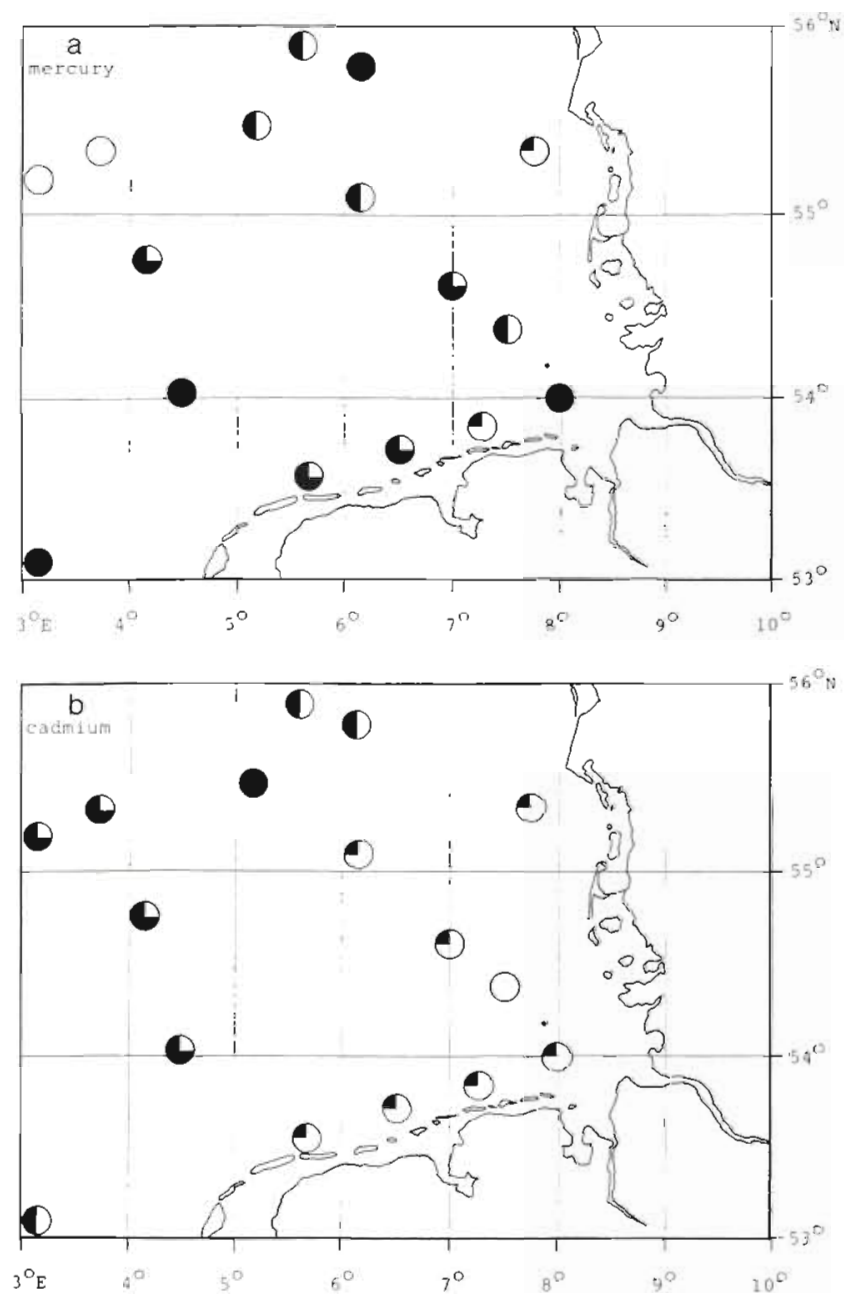

(1987a, b) and in Nephtys spp., Echinocardium cordatum and Venus striatula by Kröncke (1987). Both authors state that on a transect from the inner German Bight to the northern Doggerbank mercury concentrations decrease, while cadmium and lead concentrations increase. The same was found in the present study

Our measurements on abdominal muscles of the hermit crab Pagurus bernhardus partly confirm these findings (Fig. 10a to c). The contamination pattern for mercury is not very clear if only the southeastern part, and not the whole North Sea, is examined. High mercury values were measured in the inner German Bight, and the lowest values occurred far offshore between $3^{\circ}$ and $4^{\circ} \mathrm{E}$ and $55^{\circ}$ and $56^{\circ} \mathrm{N}$. Cadmium levels were low in the inner German Bight and rose towards the central North Sea. Lead values were relatively low in coastal areas and partly increased towards the open sea. A maximum concentration was detected between $5^{\circ}$ and $6^{\circ} \mathrm{E}$ and $55^{\circ}$ and $56^{\circ} \mathrm{N}$.

We conclude from these results that the central North Sea can no longer be regarded as an unpolluted or

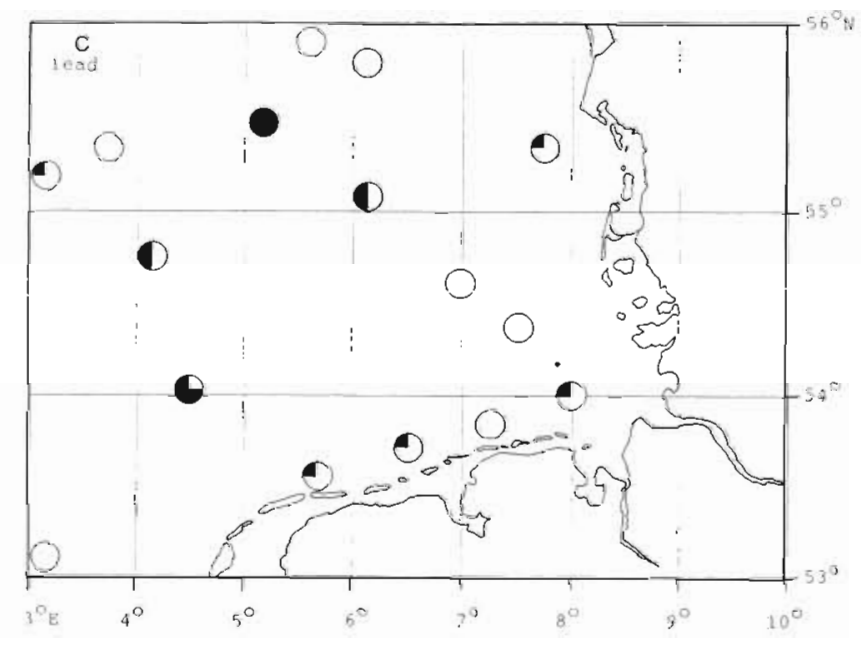

Fig. 10. Pagurus bernhardus. Trace metal concentrations (mg $\mathrm{kg}^{-1}$ ) in abdominal muscle in the southeastern North Sea.

(a) Mercury:

$O=\langle 0.15 ; \boldsymbol{O}=\geqslant 0.15 ; \boldsymbol{O}=\geqslant 0.2 ; \boldsymbol{O}=\geqslant 0.25 ; \boldsymbol{O}=\geqslant 0.3$.

(b) Cadmium:

$\mathrm{O}=\langle 0.4 ; \boldsymbol{O}=\geqslant 0.4 ; \boldsymbol{O}=\geqslant 0.8 ; \boldsymbol{O}=\geqslant 1.2 ; \boldsymbol{O}=\geqslant 1.6$

(c) Lead:

$O=\langle 0.7 ; O=\geqslant 0.7 ; O=\geqslant 1.4 ; 0=\geqslant 2.1 ; 0=\geqslant 2.8$ 
even low-pollution area. Obviously the distribution of metals in biota is not consistent with that in seawater, as seawater concentrations normally decline with distance from the coast. However, recent research shows some exceptions to this general scheme (Dicke et al. in press).

Possible explanations for this phenomenon are related to:

(1) Currents. These play a dominant role in transport processes involving dissolved and particle-bound pollutants. Hence the northern entries to the North Sea near the Shetland and Orkney Islands may not only function as an inlet for uncontaminated Atlantic Ocean water but also for the heavily polluted water masses from the Irish Sea. From here the residual currents take their course southwards along the British east coast where a large number of dumping sites are situated, and industrialized rivers like the Humber flow into the sea. According to the predominant currents, this load is partly driven to the central North Sea (Backhaus \& Maier-Reimer 1983), where particle-bound pollutants settle. This process is favoured by the circulation of water masses in certain areas of the North Sea leading to enhanced residence times. The Doggerbank serves as a suitable example. Although far from any coasts, a large number of pollutants like cadmium, DDT and PCB's reach peak values in benthic organisms and sediments, coupled with extremely high rates of fish diseases (Dethlefsen 1984). It is concluded that by sedimentation of particle-bound pollutants, the seawater is freed from contamination. However, the pollution problem is then shifted to the sea floor and its biota.

(2) Bioavailability. In metals this is generally low in estuaries, since e.g. $80 \%$ of cadmium and even $95 \%$ of lead are bound to particles (Mart et al. 1986). Hence bioavailability via seawater is extremely low. Through food intake, only small amounts of trace metals are accumulated. This is valid even for filter feeders (Borchardt 1983, Amiard et al. in press, Riisgård et al. in press). The low bioavailability of metals in estuaries was demonstrated also by Fisher \& Frood (1980) who found that offshore phytoplankton was more efficiently adapted to metal contamination than estuarine planktonic algae.

In the central North Sea only $10 \%$ of cadmium is particle bound, versus 30 to $50 \%$ of lead. Hence the decrease in total concentrations from the Elbe estuary $(\mathrm{km} \mathrm{704-727)}$ via the inner German Bight to the central North Sea (cadmium: $0.1-2.0 \rightarrow 0.03-0.08 \rightarrow 0.02-0.04$ $\mu \mathrm{g} \mathrm{l^{-1 }}$, lead: $2-15 \rightarrow 0.08-0.3 \rightarrow 0.03-0.05 \mu g \mathrm{l}^{-1}$; (Albrecht 1984, Mart et al. 1986, ARGE 1986) is counteracted by a dramatic increase in bioavailability. However, this fact can only partly explain the high levels of cadmium and lead in mussels from the open sea.
Mercury concentrations in the Elbe estuary are extremely high (20 to $200 \mathrm{ng} \mathrm{I}^{-1}$; ARGE 1986). In the inner German Bight medium concentrations between 20 and $70 \mathrm{ng} \mathrm{l}^{-1}$ are found (Albrecht 1984), decreasing towards the central North Sea to about 1 to $2 \mathrm{ng} l^{-1}$. As is well known, methyl mercury is accumulated about 10 times faster than mercury ion. In the Elbe estuary and in nearby coastal areas $20 \%$ of the total mercury occurs in its methylated form (Mart et al. 1986), while 80 to $90 \%$ is methylated in the central North Sea. Hence the 10 to $200-$ fold decrease in mercury concentrations in seawater is not counteracted by the about 4 -fold increase of the more bioavailable mercury species; consequently, concentrations in offshore organisms are lower.

(3) Remobilization of metals. In certain regions of the North Sea, oxygen deficiencies were repeatedly measured in late summer (Weichart 1984). The depletion is probably caused by increased eutrophication. Most affected are the areas northwest of Helgoland and off southern Jylland. Here, it seems possible that trace metals are remobilized from the sediments due to changes in redox conditions.

Similar remobilization processes occur in areas with pronounced hydrographical frontal systems, e.g. near the Orkney Islands (Kremling 1983) where unusually high metal concentrations were found in seawater, and consequently also in Cancer pagurus from these waters (Davies et al. 1981).

Acknowledgements. We thank L. Neugebohrn for help with the preparation of samples. Financial support was received from the 'Bundesministerium für Forschung und Technologie' (Topic: 'Zirkulation und Schadstoffumsatz in der Nordsee') from the 'Bund-Länder-Meßprogramm' ('Nordseeküstengewässer') and the 'Niedersächsisches Wasseruntersuchungsant' ('Wassergüte-Meßprogramm Jade').

\section{LITERATURE CITED}

Albrecht, H. (1984). Gütezustand der Nordsee: anorganische Schadstoffe in Wasser, in Sedimenten und in Organismen. Meereskundliche Beobachtungen und Ergebnisse 55 $38-52$

Amiard, J. C., Amiard-Triquet, C., Berthet, B., Metayer, C. (1986). Contribution to the ecotoxicological study of cadmium, lead, copper and zinc in the mussel Mytilus edulis. I. Field study. Mar Biol. 90: 425-431

Amiard, J. C., Amiard-Triquet, C., Ballan-Dufrancals, C. Berthet, B., Gillot, P., Jeantet. A. Y., Martoja, R., Truchet, $R$. (in press). Study of the bioaccumulation at the molecular, cellular and organism levels of lead and copper transferred to the oyster Crassostrea gigas Thunberg directly from water or via food. In: Proceedings of the 21st European Marine Biology Symposium, Gdansk. Institute of Oceanology, Sopot, Poland

ARGE (1986). Wassergütedaten der Elbe von Schnackenburg bis zur See - Zahlentafel 1985. Report of Arbeitsgemeinschaft zur Reinhaltung der Elbe

Backhaus, J. O., Maier-Reimer, E. (1983). On seasonal circula- 
tion patterns in the North Sea. In: Sündermann, J., Lenz, W. (eds.) North Sea dynamics. Springer-Verlag, Berlin, p. $63-94$

Boalch, R., Chan, S., Taylor, D. (1981). Seasonal variation in the trace metal content of Mytilus edulis. Mar. Pollut. Bull. 12: $276-280$

Borchardt, T. (1983). Influence of food quantity on the kinetics of cadmium uptake and loss via food and seawater in Mytilus edulis. Mar. Biol. 76: 67-76

Borchardt, T., Karbe, L., Burchert, S., Haar, E., Hablizel, H., Zeitner, R. (in press). Influence of size and body condition on metal concentrations in mussels. Implications for biological monitoring programmes. Proceedings of 21st European Marine Biology Symposium, Gdansk. Institute of Oceanology, Sopot, Poland

Claussen, T. (1987a). Enhancement of knowledge on trace metal levels in flatfish (dab, Limanda limanda) from the southern North Sea. Coun. Meet. int. Coun. Explor. Sea C.M.-ICES/E: 29

Claussen, T. (1987b). Characteristic levels and spatial distribution of trace metals in flat fish (dab, Limanda limanda) from the German Bight and the southern North Sea. Mitt. Geol.-Palaeont. Inst. Univ. Hamburg (in press)

Cossa, D., Bourget, E., Piuze, J. (1979). Sexual maturation as a source of variation in the relationship between cadmium concentration and body weight of Mytilus edulis L. Mar Pollut. Bull. 10: 174-176

Cossa, D., Rondeau, J. G. (1985). Seasonal, geographical and size-induced variability in mercury content of Mytilus edulis in an estuarine environment: a re-assessment of mercury pollution level in the Estuary and Gulf of St. Lawrence. Mar. Biol. 88: 43-49

Davies, I. M., Topping, G., Graham, W. C., Falconer, C. R., McIntosh, A. D., Saward, D. (1981). Field and experimental studies on cadmium in the edible crab Cancer pagurus. Mar. Biol. 64: 291-297

Dethlefsen, V. (1984). Diseases in North Sea fishes. Helgoländer Meeresunters. 37: 353-374

Dicke, M., Schmidt, D., Michel, A. (in press). Trace metal distribution in the North Sea. In: Proceedings of the International Conference on Heavy Metals in the Environment, New Orleans

Fischer, H. (1983). Shell weight as an independent variable in relation to cadmium content of molluscs. Mar. Ecol. Prog. Ser. 12: $59-75$

Fisher, N. S., Frood, D. (1980). Heavy metals and marine diatoms: influence of dissolved organic compounds on toxicity and selection for metal tolerance among four species. Mar. Biol. 59: 85-93

Frazier, J. M., George, S. G. (1983). Cadmium kinetics in oysters - a comparative study of Crassostrea gigas and Ostrea edulis. Mar. Biol. 76: 55-61

Green, N. W., Enger, B., Kirkerud, L., Martinsen, K., Norheim, G. (in press). Polychlorinated biphenyls, mercury and cadmium in mussel and cod and their spatial and temporal trends in the Oslofjord and Orkdalsfjord (Norway). Proceedings of the 21st European Marine Biology Symposium, Gdansk. Institute of Oceanology, Sopot, Poland

Jensen, A. (1985). Geographical trends in the concentrations of heavy metals in the blue mussel from the German Bight to Hirtshals in 1983. Preliminary report. Coun. Meet. int. Coun. Explor. Sea C.M.-ICES E: 44

Kröncke, I. (1987). Heavy metals in macrofauna of the North Sea. Coun Meet. int. Coun. Explor. Sea S.M.-ICES E: 28

Kremling, K. (1983). Trace metal fronts in European shelf waters. Nature, Lond. 303: 225-228

Latouche, Y. D., Mix, M. C. (1982). The effects of depuration, size and sex on trace metal levels in bay mussels. Mar. Pollut. Bull. 13: 27-29

Lobel, P. B. (1986). Role of the kidney in determining the whole soft tissue zinc concentration of individual mussels (Mytilus edulis). Mar. Biol. 92: 355-359

McGill, R., Tukey, J. W., Larsen, W. A. (1978). Variations of box plots. Am. Statist. 32: 12-16

Mart, L., Nürnberg, H. W (1986). Cadmium, lead, copper, nickel and cobalt distribution in the German Bight. Mar Chem. 18: 197-213

Orren, M. J., Eagle, G. A., Hennig, H. F.-K-O, Green, A. (1980). Variations in trace metal content of the mussel Choromytilus meridionalis (Kr.) with season and sex. Mar. Pollut. Bull. 11: 253-257

Phillips, D. J. H. (1976). The common mussel Mytilus edulis as an indicator of pollution by zinc, cadmium, lead and copper I. Effects of environmental variables on uptake of metals. Mar. Biol. 38: 59-69

Riisgård, H. U., Bjornestad, E., Mohlenberg, F. (in press). Accumulation of cadmium in the mussel Mytilus edulis: kinetics and importance of uptake via food and seawater Mar. Biol.

Sachs, L. (1979). Statistische Methoden. Springer-Verlag, Berlin

Talbot, V (1985). Relationship between cadmium concentration in seawater and those in the mussel Mytilus edulis. Mar. Biol. 85: 51-54

Theede, H., Andersson, I., Lehnberg, W. (1979). Cadmium in Mytilus edulis from German coastal waters. Ber. dt. wiss. Komm. Meeresforsch. 27: 147-155

Weichart, G. (1984). Gütezustand der Nordsee: Nährstoffe und gelöster Sauerstoff. Meereskundliche Beobachtungen und Ergebnisse 55: 89-99 